Utah State University

DigitalCommons@USU

$1-1-2006$

\title{
Integrating Information Literacy with a Sequenced English Composition Curriculum
}

Wendy Holliday

Utah State University

Britt A. Fagerheim

Utah State University

Follow this and additional works at: https://digitalcommons.usu.edu/lib_pubs

Part of the Library and Information Science Commons

\section{Recommended Citation}

Holliday, Wendy and Fagerheim, Britt A., "Integrating Information Literacy with a Sequenced English Composition Curriculum" (2006). Library Faculty \& Staff Publications. Paper 89.

https://digitalcommons.usu.edu/lib_pubs/89

This Article is brought to you for free and open access by the Libraries at DigitalCommons@USU. It has been accepted for inclusion in Library Faculty \& Staff Publications by an authorized administrator of DigitalCommons@USU. For more information, please contact digitalcommons@usu.edu.

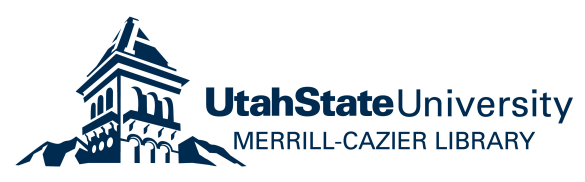




\title{
Integrating Information Literacy with a Sequenced English Composition Curriculum
}

\author{
Wendy Holliday and Britt Fagerheim
}

\begin{abstract}
This article details the process of implementing a sequenced information literacy program for two core English composition courses at Utah State University. An extensive needs assessment guided the project, leading to a curriculum design process with the goal of building a foundation for deeper critical thinking skills. The curriculum development and implementation process highlights several of the advantages of using the course-integrated model of instruction to develop a more comprehensive information literacy program.
\end{abstract}

\section{Introduction and Literature Review}

7 here has been widespread debate among academic librarians about the best way to deliver information literacy (IL) instruction. ${ }^{1}$ Much of this debate has centered on the credit-bearing course versus course-integrated or course-related instruction. Edward Owusa-Ansah summarizes these debates in an extensive review of the literature. ${ }^{2}$ Supporters of separate IL courses argue that information literacy is a discipline in and of itself and that it will only be taken seriously in the currency of higher education if disciplinary faculty teach the credit-bearing class. ${ }^{3}$ The advantage of a required credit course is that is comprehensive. All students receive similar instruction in content, scope, and depth. Assessment of student learning is also easier in a credit course taught by a librarian. Students might also be more motivated in a course for which they receive graduation credit. ${ }^{4}$

Others argue that course-integrated instruction is a more effective model. While information literacy is a general skill, students will retain IL skills and transfer learning if instruction is attached to a subject-based discipline. Ann Grafstein argues that 
teaching generic information seeking skills focuses too much on information retrieval processes, ignoring a vital connection to disciplinary content and deeper critical thinking skills implicated in the production of knowledge. ${ }^{5}$ Others have argued that credit-bearing courses are too resource intensive and that students are not attracted to separate courses. ${ }^{6}$ Adding additional general education requirements can also be difficult, given competing interests and already extensive requirements. ${ }^{7}$

At Utah State University (USU), we favor the course-integrated approach for both practical and pedagogical reasons. We do not have a credit-bearing IL course, and we face typical resource constraints that would make a mandatory credit-bearing course difficult. The USU general education curriculum is credit heavy, and students currently have a hard time fulfilling requirements in a timely fashion. We also see the pedagogical advantages of linking information literacy to disciplinary content and authentic, problem-based learning. We want to develop a more comprehensive solution, however, than spotty one-shot instruction sessions that lack a logical sequence. Our goal is to sequence IL throughout the general education and upper division curricula in ways that better meet students' needs as they advance in their coursework.

We decided to begin with a comprehensive curriculum design project for the writing (or English composition) program. This program is comprised of two required courses, Introduction to Writing (English 1010, generally taken by freshmen) and Intermediate Writing (English 2010, generally taken by sophomores or juniors). We already possessed a strong relationship with the English composition program. Most instructors had been bringing their classes in for at least one library session for both English 1010 and 2010, and the library had a good working relationship with program administrators. Barbara J. D'Angelo and Barry M. Main suggest that writing programs are natural allies for information literacy because they, too, teach more general skills used across the curriculum. ${ }^{8}$

\section{Needs Assessment}

The process at USU began with a needs assessment that used multiple methods to determine instructional goals, content, and strategies. Two main issues were evident at the beginning of the needs assessment process. First and foremost, library instruction did not seem to be meeting the needs of our current students. There was a gap between what librarians were teaching and being asked to teach by English instructors and what students actually needed. Instruction was focused on using tools such as article databases, but students had trouble focusing on a topic, selecting appropriate resources, evaluating information, and other high-order thinking skills. Students also noted that they received the same basic instruction in English 1010 and 2010. Furthermore, librarians and instructors tried to cover too much in one or two library sessions, contributing to confusion and overload.

The second issue prompting the needs assessment was resources. English instructors were asking librarians to teach more classes each semester, partly due to an increased number of English 1010 and 2010 sections overall and partly because more instructors brought classes in for multiple library sessions. Fewer librarians were available to teach these sessions, however, because of a hiring freeze and changing assignments within 
the library. By 2002-2003, librarians were teaching, on average, two more 1010 sessions (from 8.5 to 10.8) and more than twice as many 2010 sessions (from 6.7 to 14.9) than they had taught in 1999-2000.

We began by developing a series of questions that needed to be answered in order to develop an effective curriculum.

- What do our students do when conducting research? What are the gaps between what they do and what we would like them to do?

- What are the English instructors' learning outcomes for English 1010 and 2010 as they relate to information literacy? How do they identify gaps in students' information literacy?

- How do the librarians define and prioritize information literacy learning outcomes?

-Where is the common ground between librarians and English instructors?

We did not have the time or resources to conduct extensive research with USU students exclusively, so we decided to conduct a literature review of undergraduate information-seeking behavior to identify general trends among this population. We focused our review on research conducted in the last three to five years. We then conducted surveys with USU librarians and English instructors. We also held a debriefing session with librarians, following an initial survey. Through discussion, we reached a consensus on learning goals and refined the results of the librarian survey.

\section{Student Behavior}

It came as little surprise that a wide range of literature shows that students prefer the World Wide Web to library resources. ${ }^{9}$ Students value the Web for its speed and convenience. ${ }^{10}$ Citation analyses show that students are using the Web for research assignments, often supplementing more traditional sources such as scholarly articles. ${ }^{11}$ When looking at actual search behavior, Stacy Nowicki found that students tend to be novice searchers. Many students use a single, broad term that would be unlikely to yield clear and specific results. Few students use advanced search features. ${ }^{12}$ While students prefer the Web for its convenience, Barbara Valentine noted that students do try to figure out what the instructor wants in a research paper. They are focused on assignment requirements for the type and number of sources. They are often more focused on these requirements than thinking critically about the "best" sources to address their research questions. ${ }^{13}$

From the review of the literature, librarians at USU identified the knowledge of different information sources as a primary gap in information literacy skills. Students are fairly confident in their search abilities, but they tend to do research superficially, focusing on assignment requirements, familiarity, and convenience rather than looking for the best possible information to address their needs. ${ }^{14}$ Preliminary results of a study of English composition students at USU confirmed these more general trends.

\section{Librarian Surveys}

USU reference librarians completed a survey to determine which learning outcomes (based on the ACRL Information Literacy Competency Standards for Higher Education ${ }^{15}$ ) 
should be taught in English 1010 and in English 2010 or whether they should be prerequisites for college or taught in advanced courses. Librarians were also asked to rate each learning goal (taken from the performance indicators of the ACRL standards) for level of coverage ( 1 =minimal; $2=$ partial; $3=$ complete). A follow-up discussion was held to clarify the results, and librarians reached a consensus on their ideal scope and sequence of learning goals.

In general, librarians thought that English 1010 students should be introduced to concepts and skills such as how to identify different types of information and how to evaluate and use information. They should master skills such as defining their information need, searching effectively, and citing sources. Table 1 summarizes the depth of coverage proposed for English 1010.

Librarians thought that English 2010 students should review concepts and skills such as determining an information need, effective searching, and citing sources. They should also receive more instruction in information evaluation and use. Complete mastery of many of these skills, however, should be taught in discipline-specific courses in the major, which would build on the basic skills taught in English 1010 and 2010. Librarians suggested partial coverage of most of the 22 skills and concepts outlined in the survey (table 2).

Reference librarians were also asked to complete a survey to determine who should take responsibility for teaching and assessing information literacy skills (1=librarians; 2=English instructors; 3 =shared). Twenty-two skills were included in the survey, based on the previous survey. Most librarians wanted primary responsibility for teaching skills under standards one and two, those having to do with selecting appropriate resources and search tools and conducting effective searches. Librarians felt that English instructors should be responsible for those skills that involve integration and synthesis of information and information use. Librarians identified skills related to defining information needs, evaluating sources, and ethical and legal issues as shared responsibilities.

\section{English Instructor Survey}

The next step was to survey English 1010 and 2010 instructors to determine their information literacy priorities. We used the ACRL Information Literacy Standards as a framework to begin a conversation about the scope and depth of information literacy. The librarians first simplified the wording of several of the standards, focusing on the 22 performance indicators that librarians had ranked in their survey (see appendix A, http:/ / muse.jhu.edu/journals/pla/v006/supp_open/6.2holliday_appendixA.doc). While some librarians had shared the ACRL standards with individual instructors in previous instructional planning, most instructors had never seen them before. English instructors also did not know how librarians had ranked the skills. Our goal was to see how instructors' priorities agreed or disagreed with those of librarians. We asked English instructors to rate the level of need for students to learn each of the 22 information literacy skills. They rated skill importance using a Likert scale ( $1=$ very low need and $5=$ very high need). We asked instructors to rate the importance of these learning goals for both English 1010 and 2010. Consequently, one goal might be rated as more important for the 2010 course than for the 1010 course. We encouraged instructors to 


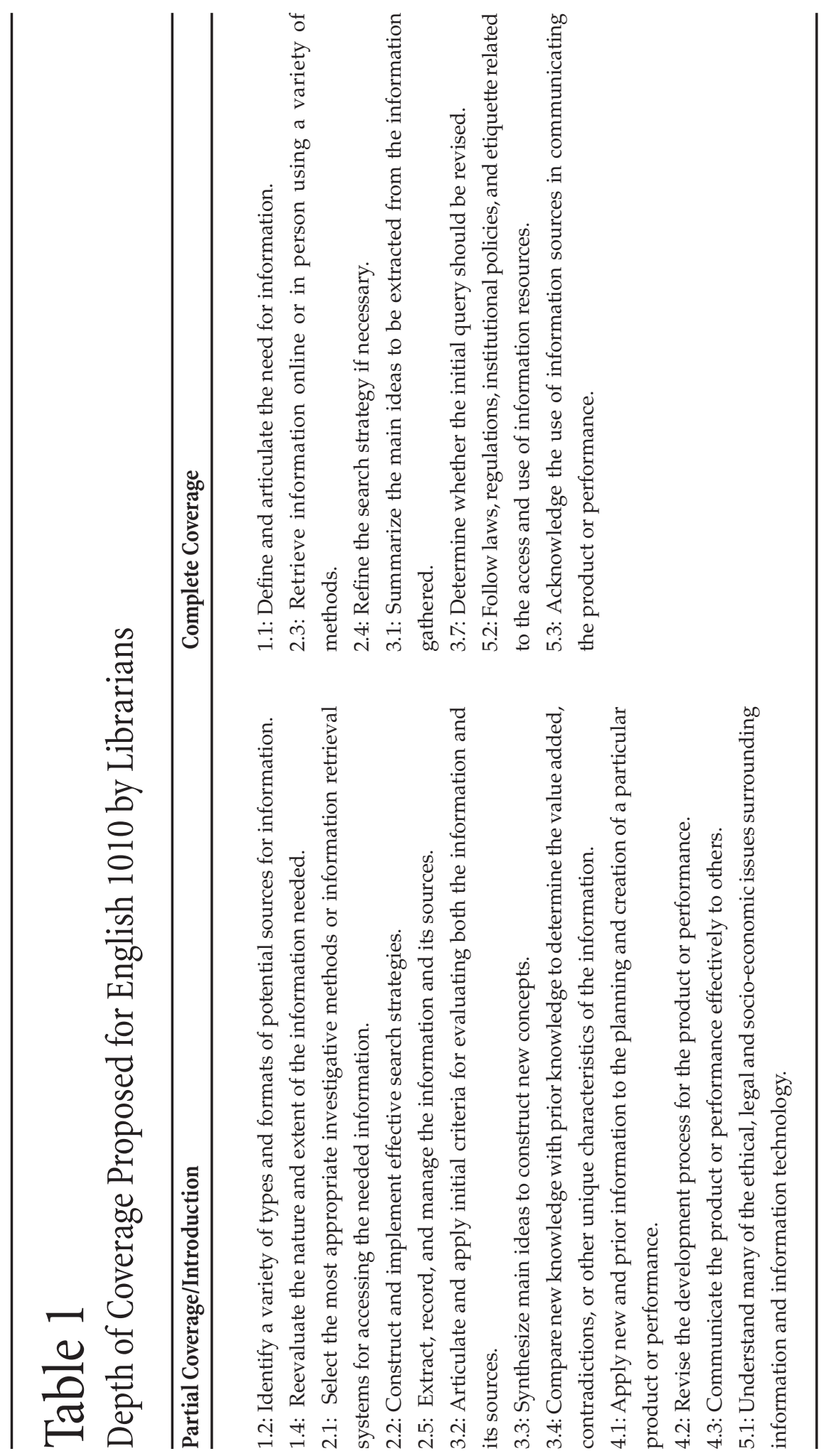




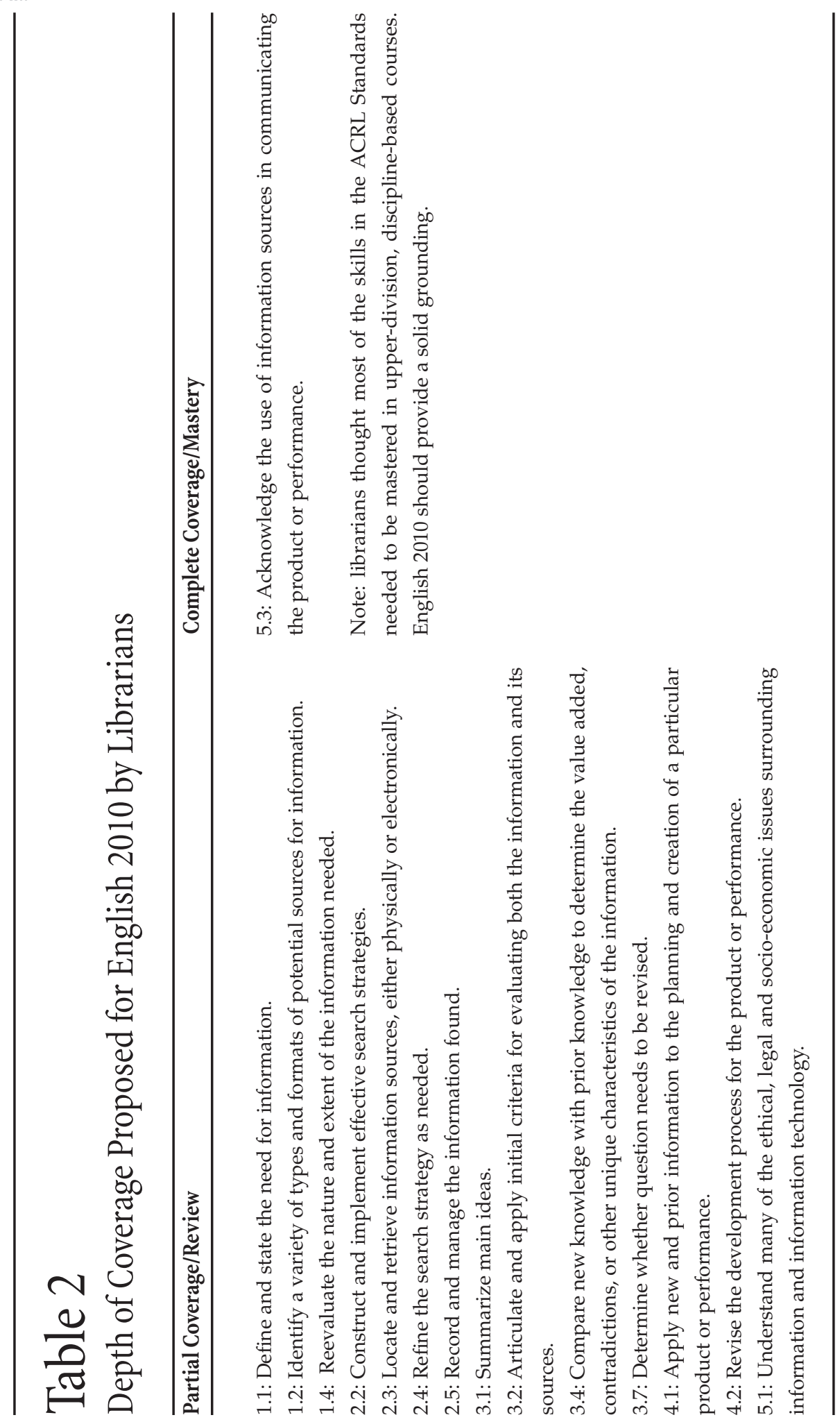


rate the learning goals according to what they thought would be ideal, not according to what was being taught currently. We sent a Web-based survey to all of the English 1010 and 2010 instructors in April 2004, including concurrent enrollment instructors who taught English 1010 at the local high schools (for a total of 64 surveys distributed). We received 22 usable surveys, for a response rate of 34.4 percent.

The results suggest that approximately 80 percent of the instructors rate all 22 skills as being of medium to very high importance in English 1010. There were very few "not rated" ratings for these 22 skills, with only five skills receiving any "not rated" ratings. Few skills received low or very low ratings. In general, the instructors tended to rate the skills corresponding to ACRL standards one and two (determining an information need and accessing information effectively) as being more important than skills in standards three, four, and five (evaluating information, using information, and using information ethically). The skills under standard four received the lowest ratings in both English 1010 and 2010 (table 3).

For English 2010, approximately 50 percent of the instructors rated all 22 skills as being of medium to very high importance. All skills had between six and eight "not rated" ratings, accounting for approximately 30 percent of the ratings. It is likely that some English 1010 instructors did not think they should rate skills for an English 2010 class that they had not taught. Almost all of the "not rated" skills came from surveys in which skills were rated for English 1010 but were left blank for English 2010. If the "not rated" ratings are dropped from the analysis, approximately 85 percent of the instructors rate all of the skills as being of medium to very high importance to English 2010 students. Only one skill (4.2) falls below that 85 percent level. In comparison to English 1010 ratings, there is an increase in the importance of skills under ACRL standards one, three, and four for English 2010 (table 4).

When looking at the results of both the librarian and English instructor surveys, common themes and priorities appear. We used these commonalities as the basis for developing more sequenced instruction for English 1010 and 2010. The commonalities also confirm recent trends in student behavior found in the literature. Both librarians and English instructors placed a high priority on standards one (defining the nature and extent of the information need) and two (accessing needed information effectively and efficiently). In the case of standard one, librarians felt that students should have complete mastery of the skill of defining and articulating the need for information (ACRL standard performance indicator 1.1) by the end of English 1010. In English 1010, they should also be able to begin to identify various types of information formats and sources, and they should start to reevaluate the nature and extent of their information need after they have done some background reading. Instruction in English 2010 should build on these latter two skills, introducing students to a wider range of information sources and having them reflect more deeply on their information needs.

English instructors rated all of the standard one skills from high to very high in English 1010 and medium to very high in English 2010, confirming the notion of introducing the skills in 1010 and building on them in 2010. For standard two (access needed information effectively and efficiently), English instructors rated all of the constituent skills high to very high. Librarians thought that English 1010 students should master the skills of constructing a search strategy, retrieving information physically or online, 


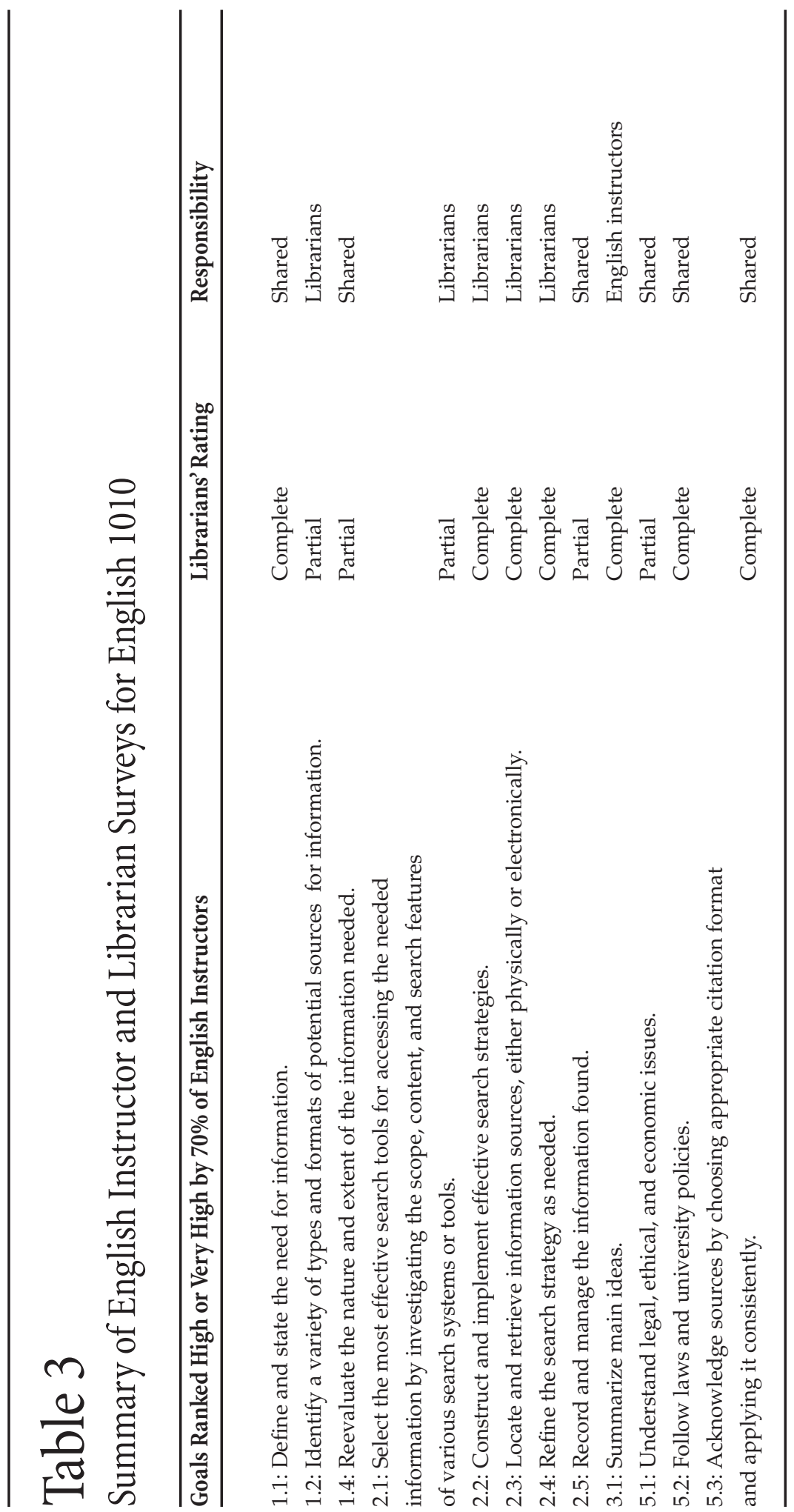




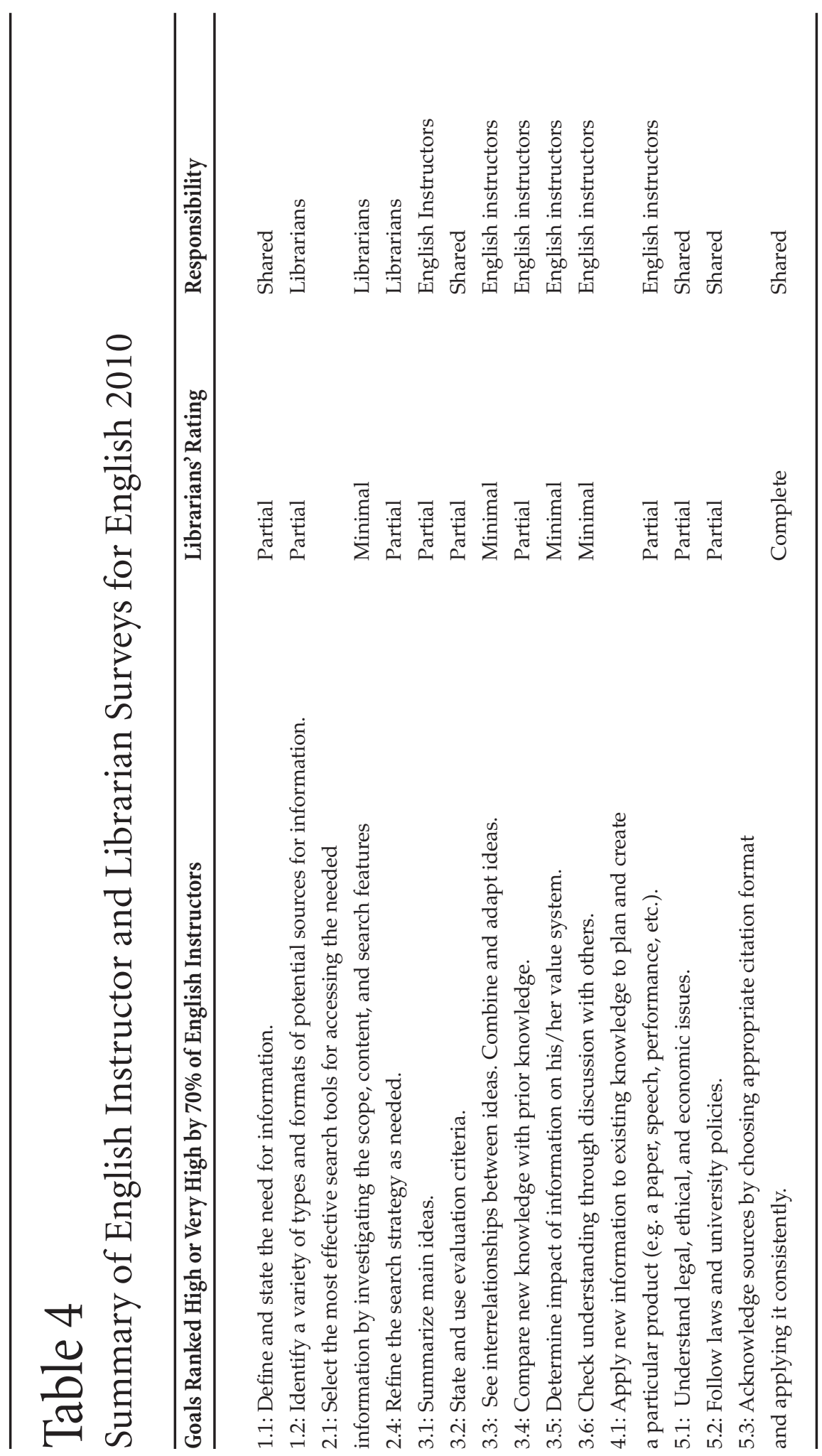


and refining the search strategy. In English 2010, students should review these skills and refine them in more sophisticated ways. There was also widespread agreement that this was the primary area of librarian expertise and that they should be responsible for teaching and assessing these skills.

Standard three relates to evaluating information. Students need to evaluate information for credibility and accuracy. They also need to evaluate whether the information answers their questions, changes their opinions, and is appropriate for their product or their assignment. For English 1010, instructors ranked these skills moderately, as did librarians. Students should be introduced to criteria for evaluation and begin to reflect on the information they find and how it relates to their existing knowledge. English instructors ranked these skills higher for 2010 students, and librarians proposed that students refine these skills at this level. Librarians felt that the primary responsibility for teaching and assessing these skills should rest with English instructors, with some support from librarians in evaluating sources for appropriateness and credibility.

Standard four (using information effectively to accomplish a specific purpose) was rated in a similar way. English 1010 students should begin to work on using information to plan and create a product such as a paper or presentation. The emphasis, however, should be on more personal reflection and integration rather than on specific requirements or constraints such as providing evidence for a particular argument. Students should build on these skills in English 2010 and in upper-division classes. The products in these upper-level classes, for example, would be more sophisticated, requiring a wider range of sources, greater synthesis and integration, and greater emphasis on evidentiary requirements and the perspectives of different disciplines or audiences. Primary responsibility to teach and assess this area should rest with the English instructors.

English instructors and librarians ranked standard five (using information ethically and legally) as high for both English courses, possibly reflecting growing concerns about plagiarism. By the end of English 1010, librarians felt that students should be able to follow laws, regulations, and institutional policies regarding the access and use of information sources. They should also be able to acknowledge those sources using proper citation styles. In English 2010, students should review these skills and also be introduced to legal and socio-economic issues related to the production and dissemination of information (such as public access to information paid for by the government or the concept of academic disciplines and the invisible college). Librarians felt that teaching and assessing these skills is a shared responsibility.

\section{Curriculum Development}

\section{English 1010}

As the library set about revising the curriculum for information literacy, the English Department was beginning a revision of its curriculum for English 1010. The close relationship that existed between the library and the English Department enabled the collaboration that was required to successfully introduce information literacy into the English curriculum. Building a relationship with academic departments is critical to the success of an integrated, sequenced information literacy program. ${ }^{16}$ In addition, all English 1010 instructors follow a common curriculum fairly closely. This allowed 
the librarians to develop set lesson plans, which they could modify as necessary to fit each class.

In the newly adopted text for English 1010, Rereading America, cultural myths are used to engage students in the process of critical thinking by asking questions about their own assumptions and perspectives. ${ }^{17}$ Rereading America also uses the metaphor of conversation. Students are encouraged to engage in a dialogue when reading the book selections, and many of the pieces speak to each other. The library instruction curriculum seeks to present libraries as a repository for many voices and as places to extend the conversation further. ${ }^{18}$

The new English 1010 library cur-

The close relationship that existed between the library and the English Department enabled the collaboration that was required to successfully introduce information literacy into the English curriculum. riculum aims to introduce students to the world of information and provide a foundation for critical inquiry during their college years. ${ }^{19}$ The lessons are designed to cumulatively support and build on the following five basic learning outcomes:

1. Define and state the need for information

2. Identify a variety of types and formats of potential sources for information

3. Select the most effective search tools for accessing the needed information by investigating the scope, content, and search features of various search systems or tools

4. Construct and implement effective search strategies

5. Evaluate sources and information in order to decide whether or not to use it or make it part of a personal knowledge base and value system

Following instructional design practice, we articulated specific learning objectives and developed activities to support the objectives. ${ }^{20}$ The curriculum is divided into four lessons. Two lessons take place in the English classroom and last for 30-35 minutes, and two take place in the library and last for approximately 50 minutes. The first lesson, Information as a Conversation, uses library resources as a microcosm to discuss types of information. ${ }^{21}$ The second lesson, Subject-Based Library Tour, explores the areas in the library where students can find information types discussed in the first lesson as related to class topics. The third lesson, Information Organization, uses sample citations printed from different search tools to simulate queries on a topic. The final lesson, Information Search Challenge, involves one-on-one search help and a "librarian challenge," in which students are able to watch the librarian model the search process. ${ }^{22}$

During each lesson, librarians prompt students to reflect on the different kinds of information presented to them. Students are not expected to master all the skills; the goal is to introduce them to a variety of information sources so that they can think more critically about sources and their information needs. Students gain a conceptual foundation of how information is organized and described, so they can develop better search skills and transfer their knowledge to multiple situations and research tools. 


\section{English 2010}

A different set of issues arose as we designed the information literacy curriculum for the English 2010 course. First, English 2010 students have a greater variety of competency levels and, therefore, the curriculum needs to address this diversity. Some students have taken English 1010 and have a common foundation on which to build. Others have tested out of English 1010 or transferred credits, so these students have different levels of experience in and training for library research.

Second, English 2010 instructors do not teach from a standard curriculum. Instructors emphasize different texts and methods and have varied levels of experience teaching 2010. Some instructors want to collaborate closely with librarians, whereas others prefer a train-the-trainer approach so that they can teach much of the information literacy instruction themselves. A few instructors have very little contact with the library.

To address these issues, we developed a set of learning outcomes and proposed activities and assessments from our analysis of the most commonly used English textbook and our needs assessment. This involved mapping the learning goals from each chapter of the text to the ACRL Information Literacy Competency Standards. ${ }^{23}$ We then prioritized the goals based on the needs assessment. To accommodate the varied syllabi of English 2010, we developed a modular curriculum with a menu of options available to instructors and librarians for teaching various information literacy goals. Instead of developing single activities for each learning goal, we organized multiple related learning goals into the following groups:

- Group one: topic selection, background research, and focus formulation

- Group two: identification of potential sources of information

- Group three: search skills

- Group four: evaluation and iteration

- Group five: management of information and citation of sources

Within each of these groups, we identified core and supplementary activities. The core activities are more integrated, teaching several related skills at once. Supplementary activities are more focused on single skills or learning goals and are designed to prepare students for a core activity.

We also created three model sequences to illustrate how select learning activities and modules could be sequenced through the curriculum. The problem-based sequence uses problem-based learning as a teaching strategy. ${ }^{24}$ The advantages of problem-based learning are that it helps students learn authentic skills with real problems and helps them transfer that learning across multiples assignments during their course of study. In the student topic sequence, students focus on their own research topics. The advantage to this approach is that students' immediate needs are addressed. The online-based sequence uses Web-based tutorials while still including one face-to-face visit with a librarian. ${ }^{25}$

We suggested instructors integrate activities and assessments into existing assignments. Some instructors assigned a topic proposal memo that included a student assessment of potential information resources, which the librarian evaluated and provided feedback to help students further develop their research skills. We also worked with instructors to incorporate a double-entry journal into the syllabus, to be used to assess whether an information need was met or whether new questions needed to be asked. 
By offering a menu of options for teaching the information literacy standards, English instructors were able to pick and choose among a variety of activities and approaches. Through close collaboration between instructors and librarians, we have been able to begin to integrate information literacy into the English 2010 curriculum despite varied teaching methods and students' skills levels.

\section{Conclusions}

USU librarians and English instructors implemented the new curriculum in fall 2004. We used a variety of assessment methods to evaluate the curriculum, both from the standpoint of student learning and more practical implementation issues. Students from a sample of classes answered a self-assessment survey upon completion of their research paper. The survey asked students to reflect on their own learning. We also held a "learning circle" discussion, which is an informal focus group, with three English 1010 and 2010 students to explore in more detail what they had learned throughout the semester. Ten English 1010 and 2010 instructors completed a survey asking them to reflect on their students' learning and performance on their research-based assignments. We also talked informally with English 1010 and 2010 instructors throughout the semester to evaluate how to improve the curriculum.

All of the English instructors surveyed said that students' research met their expectations in terms of quality. Ninety percent of these instructors said that students appeared to be more confident after the library sessions, which met a major goal of the English 1010 curriculum. In their comments, especially for the English 1010 classes, instructors noted that students used higher quality and more relevant sources in their assignments. One instructor noted that students even used more creative sources rather than just newspapers, journal articles, and books.

For English 1010, the vast majority of students said they learned something new as part of the library instruction. One learning circle participant, for example, stated that he actually used some library materials for his assignments rather than just surfing the Web. He also said he felt more comfortable and confident in the use of the library, which was a major goal of the English 1010 curriculum. For these classes, students were also positive about knowing where to get help.

For English 2010, nearly 78 percent of students said they learned something new. Students identified searching library databases, especially subject specific databases that applied to their projects or majors, as the most useful new skill gained from the instruction. When asked to reflect on their gaps in knowledge and skills, students said they still needed help with narrowing topics and locating physical items in the library.

From these preliminary assessments, students did seem to learn more about the library resources available to them, ranging from specific databases to reference books. Both students and instructors noted that students used library resources rather than only the Web in their final papers. Students also felt more comfortable asking for help. In these ways, the new library curriculum met most of its learning objectives, including introducing students to a wider range of resources. Informally, librarians noted that more English 1010 students asked for help at the reference desk and that they asked much more focused and sophisticated questions. 
From a more practical perspective, there were some difficulties implementing the new curriculum, especially in English 1010. The English curriculum itself was new and untested. Many instructors felt that it was overloaded with assignments and that they did not have enough time to cover the material, so instructors sometimes cut the library component at the last minute. In response to these difficulties, we modified the lessons so that they could be combined into two or three visits, including a shorter introductory discussion with fewer sample information sources. There were fewer difficulties because of the menu of options approach for English 2010. Most instructors did work with their librarians to design sequences of instruction based on the menu of options. Several instructors changed their approach to library instruction, adding new lessons in concept mapping and evaluation. Others still wanted a more traditional single-shot session, but these were in the minority. A few English 2010 instructors found the English 1010 library curriculum appealing and borrowed elements for their classes, including focused tours and a hands-on introduction to different information sources.

Despite the time constraints in English 1010, the new library curriculum was a success in a fundamental way. The English Department, especially the English 1010 coordinators, saw the need for even greater integration of the library into the English writing curriculum. English instructors realized just how long it takes to teach informa-

\section{English instructors realized just how long it takes to teach information literacy skills, and improved student work proved to them that it was worth the time.}

tion literacy skills, and improved student work proved to them that it was worth the time. The process also highlighted the need to build the library into the new English curriculum from the beginning rather than reacting to a completed curriculum. For English 2010, instructors saw the need to incorporate library lessons into their syllabi early on in order to be more effective. In our

revisions during the summer of 2005, our emphasis was on the best way to integrate the library and English curricula, so that library instruction is seen as something that supports larger learning objectives related to writing and critical thinking rather than an add-on that detracts from class time. For both English 1010 and 2010, we have developed problem-based assignments in which instructors and librarians team-teach an entire research unit.

Ongoing assessments are a core component of the new curriculum. Currently, librarians are working with English 2010 instructors to assess student learning using a pre- and post-assessment. Other assessment techniques include reviewing students' bibliographies according to a rubric and providing feedback to each student.

The new curriculum met our primary objective of using an established faculty partnership to begin building a comprehensive information literacy curriculum in the course-integrated model. While we are still conducting a more summative assessment of student learning, our preliminary assessment shows that the curriculum does improve student performance on research papers and that students identify learning something new. Observation and anecdotal evidence from both librarians and English instructors suggest that the curriculum builds upon the advantages of the course-integrated model. While relatively time-intensive, we managed to deliver instruction with our existing 
staff. We strengthened an existing librarian/faculty relationship rather than facing the political and resource battles of lobbying for a credit course. Students were engaged in authentic assignments that required research and consultation with librarians. The success of the first year enabled us to further integrate library instruction into the writing program, including the sharing of student work for assessment purposes.

The primary success of our project, however, was simply making information literacy instruction less invisible in terms of its scope and depth and the time required to teach it effectively. Librarians and the English Department are communicating this reality to other campus constituencies, including our General Education and First-Year Experience Committees. This has generated more conversations and greater potential to further develop a comprehensive, course-integrated information literacy curriculum across campus.

Wendy Holliday is coordinator of library instruction, Utah State University, Logan, UT; she may be contacted via e-mail at: wendy.holliday@usu.edu.

Britt Fagerheim is reference librarian, Utah State University, Logan, UT; she may be contacted via e-mail at: britt.fagerheim@usu.edu.

\section{Notes}

1. For our purposes at USU, we define information literacy as the ability to find, evaluate, and use information in a legal and ethical manner.

2. Edward K. Owusu-Ansah, "Information Literacy and Higher Education: Placing the Academic Library in the Center of a Comprehensive Solution," The Journal of Academic Librarianship 30, 1 (2004): 3-16.

3. Bill Johnston and Sheila Webber, "Information Literacy in Higher Education: A Review and Case Study," Studies in Higher Education 28, 3 (2003): 335-52.

4. Ibid.

5. Ann Grafstein, "A Discipline-Based Approach to Information Literacy," The Journal of Academic Librarianship 28, 4 (2002): 197-204.

6. Diane Zabel, "A Reaction to 'Information Literacy and Higher Education,'” The Journal of Academic Librarianship 30, 1 (2004): 17-21.

7. See, for example, Susan Carol Curzon, "Developing Faculty-Librarian Partnerships in Information Literacy," in Integrating Information Literacy into the Higher Education Curriculum, ed. Ilene Rockman (San Francisco: Jossey-Bass, 2004), 29-45.

8. Barbara J. D'Angelo and Barry M. Maid, “Moving Beyond Definitions: Implementing Information Literacy across the Curriculum," The Journal of Academic Librarianship 30, 3 (2004): 212-17. For more on writing across the curriculum, see James K. Elmborg, "Information Literacy and Writing Across the Curriculum: Sharing the Vision," Reference Services Review 31, 1 (2003): 68-80.

9. Steve Jones, The Internet Goes to College: How Students are Living in the Future with Today's Technology, Pew Internet and American Life Project (September 15, 2002), http:/ /www. pewinternet.org/PPF/r/71/report_display.asp (accessed December 13, 2005); Ethelene Whitmire, "The Relationship between Undergraduates' Background Characteristics and College Experiences and Their Academic Library Use," College \& Research Libraries 62, 6 (2001): 528-40.

10. Christopher Armstrong et al., "A Study of the Use of Electronic Information Systems by Higher Education Students in the UK," Program-Electronic Library and Information Systems 35, 3 (2001): 241-62. 
11. Philip M. Davis, "Effect of the Web on Undergraduate Citation Behavior: Guiding Student Scholarship in a Networked Age," portal: Libraries and the Academy 3, 1 (January 2003): 41-51.

12. Stacy Nowicki, "Student vs. Search Engine: Undergraduates Rank Results for Relevance," portal: Libraries and the Academy 3, 1 (January 2003): 503-15.

13. Barbara Valentine, "The Legitimate Effort in Research Papers: Student Commitment versus Faculty Expectations," The Journal of Academic Librarianship 27, 2 (2001): 107-15.

14. Wendy Holliday and Qin Li, "Understanding the Millennials: Updating Our Knowledge About Students to Improve Library Instruction," Reference Services Review 32, 4 (2004): 356-66.

15. Association of College and Research Libraries, Information Literacy Competency Standards for Higher Education, American Library Association (2000), http:/ /www.ala.org/ala/acrl/ acrlstandards/informationliteracycompetency.htm (accessed December 13, 2005).

16. Christine Black, Sarah Crest, and Mary Volland, "Building a Successful Information Literacy Infrastructure on the Foundation of Librarian-Faculty Collaboration," Research Strategies 18, 3 (2001): 215-25.

17. Gary Colombo, Robert Cullen, and Bonnie Lisle, Rereading America: Cultural Contexts for Critical Thinking and Writing, 6th ed. (Boston: Bedford/St. Martins, 2004).

18. We found models for our "conversational" approach from Paula McMillen and Eric Hill, "What's a Conversational Model of Research Got to Do with Information Literacy" (paper, LOEX-of-the-West Conference, Boise, ID, June 4, 2004), http:/ /library.boisestate.edu/ loex2004/presentations/PMcMillenSession5HatchB.ppt (accessed December 13, 2005); Jeanne R. Davidson and Carole Ann Crateau, "Intersections: Teaching Research through a Rhetorical Lens," Research Strategies 16, 4 (1998): 245-57.

19. Many librarians have written about the need to teach broader and deeper thinking skills. See, for example, Esther S. Grassian and Joan R. Kaplowitz, "Critical Thinking," in Information Literacy Instruction: Theory and Practice, ed. Esther S. Grassian and Joan R. Kaplowitz (New York: Neal-Schuman, 2001), 111-6.

20. Robert M. Gagne, Leslie Briggs, and Walter W. Wagner, Principles of Instructional Design, 4th ed. (Fort Worth: Harcourt Brace Jovanovich College Publishers, 1992).

21. We found a model in Troy A. Swanson, "A Radical Step: Implementing a Critical Information Literacy Model," portal: Libraries and the Academy 4, 2 (April 2004): 259-73.

22. For copies of these lessons, please contact the authors.

23. Association of College and Research Libraries.

24. See, for example, Linda Willingham, Patricia Carder, and David Bibb, "Case-Based, Problem-Based Learning Information Literacy for the Real the World," Research Strategies 18, 3 (2001): 181-90; Alexius Smith Macklin, “Integrating Information Literacy Using Problem-Based Learning," Reference Services Review 294 (2001): 306-14.

25. For copies of these lessons, please contact the authors. 